\title{
Characterisation of Rice Production Systems in Northern Agro-Ecological Zone, Uganda
}

\author{
G. O. Akongo ${ }^{1,2}$, W. Gombya-Ssembajjwe ${ }^{1}$, M. Buyinza ${ }^{1}$ \& J. J. Namaalwa ${ }^{1}$ \\ ${ }^{1}$ School of Agricultural Sciences, Makerere University, Kampala, Uganda \\ ${ }^{2}$ National Agricultural Research Organization (NARO), Entebbe, Uganda \\ Correspondence: G. O. Akongo, National Agricultural Research Organization, NARO, P.O. Box 295, Entebbe, \\ Uganda. Tel: 256-7-7234-2974. E-mail: gracelinako@yahoo.com
}

Received: December 30, 2016

doi:10.5539/jas.v10n1p272
Accepted: October 10, 2017

Online Published: December 15, 2017

URL: https://doi.org/10.5539/jas.v10n1p272

\begin{abstract}
Rice growing is an important source of food and income to the farming community in the northern agro-ecological zone (NAEZ) of Uganda. NAEZ comprised of 16 districts which form Acholi and Lango sub-regions and it is categorized by tropical dry climate with bimodal rainfall patterns. However, inspite of the importance of rice in the NAEZ, very little information exists that could support prioritization of development in the sector. This paper therefore, bridges information gap by analyzing characteristics of rice production system in the study area based on data obtained from a field survey conducted during 2016. The study used cross-sectional design to collect data which was analysed using the descriptive statistics of the STATA computer package. The results revealed marked difference in households' characteristics, production output and input utilization, production practices and constraints between lowland and upland systems. The study has concluded that: climate variability, pest and diseases, lack of improved seed variety, labour related constraints and lack of specialization are potential causes of low rice production and productivity in the NAEZ. However, to improve production performance of the systems, the study recommends promotion of climate smart farming in rice and further research into system based effects of climate on productivity as well as farmers' adaptation to climate variability.
\end{abstract}

Keywords: agro-ecological zone, characteristics, lowland, production system, rice, upland

\section{Introduction}

Rice growing in Uganda started as early as 1904 but became noticeable as food crop during the 1950s mainly to feed the Second World War veterans and government institutions such as schools, prisons and hospitals (Odogola, 2006; Bua \& Ojirot, 2014). However, rice production gained importance as cash crop after the establishment of Kibimba rice irrigation scheme in the 1960s followed by Doho and Olweny irrigation scheme in the 1970s (Odogola, 2006; GoU, 2009). Subsequently, rice growing spread throughout the country. The majority of the rice growers are small holders found especially in eastern and northern parts of Uganda, depending on rain-fed lowland rice production system.

Due to the growing importance of rice to the country's economy, the government of Uganda through agricultural and rice sector development and investment plans is rehabilitating irrigation schemes in the country including Agoro and Olweny irrigation scheme in the NAEZ (GoU, 2009, 2010). As a result of this effort, rice cultivation has rapidly grown in the northern agro-ecological zone of Uganda. In Uganda, rice production is carried out under three systems namely: irrigated system, lowland rain-fed system and upland rain-fed system. However, in the NAEZ production is currently done under two systems, i.e. rain-fed lowland and rain-fed upland.

In spite of ever growing importance of rice cultivation as source of food and income to the farming community in the NAEZ, information on its production characteristics has not been documented. Yet, this information is very crucial in farm analysis so as to prioritise the type of investment in the sector. Available literature on production include: abstract information on rice output and acreage under production on a sample of 8 districts in the NAEZ (UBOS, 2007, 2010); status of rice production, processing and marketing in Uganda (Odogola, 2006); rain-fed rice farming system based on differences in regions, varieties and yield (Haneishi et al., 2013); and effects of climate variability on technical efficiency of rice production in Acholi and Lango sub-regions (Akongo 
et al., 2016). Therefore, the study objective was to analyse characteristics of rice production systems in the northern agro-ecological zone.

\section{Methodology}

The study was a cross sectional survey conducted in northern agro-ecological zone, Uganda. The NAEZ covers an area of $42,021.2 \mathrm{~km}^{2}$ with mean annual rainfall of $1464 \mathrm{~mm}$. The mean annual temperature ranges from $17{ }^{\circ} \mathrm{C}$ to $31^{\circ} \mathrm{C}$, respectively (LDPU, 2011; GoU, 2012; GWIEA, 2013; UBOS, 2016; UNMA, 2017). It has flat topography and the soil is clay-loamy (FAO/UNEP, 1992; IUSS, 2015). The study population consisted of rice farming households and a multi-stage stratified sampling procedure was used to select a total sample of 240 (Haneishi et al., 2013). Data was collected using a semi-structured questionnaire through face to face interviews (Bua \& Ojirot, 2014). Data collected included information on household characteristics (age, household size, labour, land, crops grown and), output and inputs, (yield, area cultivated, seeds, man-days of labour, ox-plough, tractor and agro-chemicals), production practices (seasonal and monthly activity calendar and method of cultivation), disposal of proceeds and constraints in production. Data was entered using excel spreadsheet and since the purposes of this paper was to show the characteristics of rice production systems, no sophisticated statistical methods, beyond simple statistical tests for sample means (t-test and multiple comparison) were used (Haneishi et al., 2013). Analysed thus performed using descriptive statics of STATA statistical package version 13 (Bagamba, 2007; Akongo et al., 2016).

\section{Results and Discussion}

\subsection{Characteristics of Rice Producing Households}

Table 1. Characteristics of rice producing households in the NAEZ, 2013-2016

\begin{tabular}{|c|c|c|c|c|c|c|}
\hline & \multicolumn{2}{|c|}{ NAEZ } & \multicolumn{2}{|c|}{ Lowland } & \multicolumn{2}{|c|}{ Upland } \\
\hline & Mean & Std. Dev. & Mean & Std. Dev. & Mean & Std. Dev. \\
\hline Age (years) & $34.75^{*}$ & 11.964 & 35.84 & 13.072 & 33.65 & 10.643 \\
\hline Household size (No. of people) & $5.77 *$ & 3.747 & 5.11 & 3.397 & 6.43 & 3.962 \\
\hline Labour for rice (No. of people) & 3.05 & 1.741 & 3 & 1.719 & 3.09 & 1.762 \\
\hline Total land holding (Ha) & $3.40^{*}$ & 5.049 & 1.79 & 1.426 & 5.01 & 6.617 \\
\hline Land for rice $(\mathrm{Ha})$ & $1.48 *$ & 1.811 & 1.01 & 1.69 & 1.94 & 1.81 \\
\hline Number of crops grown in a year & 3.65 & 2.185 & 3.69 & 2.61 & 3.61 & 1.656 \\
\hline Household income in Shs (million) & $3.52 *$ & 4.138 & 3.04 & 4.169 & 3.99 & 4.056 \\
\hline Rice income in Shs (million) & $1.59 *$ & 2.307 & 1.28 & 2.068 & 1.89 & 2.488 \\
\hline Obs & 960 & & 480 & & 480 & \\
\hline
\end{tabular}

Note. T-test for the mean difference between the lowland and upland significance levels are represented by: * $1 \%$, ** $5 \%$, and $10 \%$.

The characteristic of rice producing households is presented in Table 1. The average age of the household head for rice producers in the NAEZ was 35 years. A relatively youthful age means that rice production constitutes productive population. However, age varied between the systems and was significantly different at $1 \%$ with lowland system having older farmers (36 years). The average household size was approximately 6 people which exceed national average size of 5 people (UBOS, 2016). However, the household size between lowland and upland systems were statistically different at $1 \%$ level of significance. About 3 household members, approximately $1 / 2$ of the household population contributed labour for rice production in the NAEZ. Test for mean difference showed that there was no significant difference in distribution of labour between the two rice systems. However, the low ratio of household labour to total household size points to the likelihood of dependency status of household population where some members are unproductive. Secondly, households grow an average of four crops annually and this means that rice production was competing with other crop activities which require the same family labour.

An average land holding size in the NAEZ was 3.4 hectares which was above the national land holding of 1.1 hectares (UBOS, 2010). However, distribution of holding in respect to the lowland and upland systems varied in sizes. An average in lowland was approximately 1.8 hectares while upland nearly tripled the size in lowland at 5 hectares. There was also a significance mean difference in the holding size allocated to rice between the two systems. Lowland farmers were allocating 1 hectare on average while the upland farmers allocated 
approximately 2 hectares of the total holdings. However, the low proportion of household land allocated to rice could be attributed to high crop diversification in the NAEZ. In fact, on average farmers grow four crops per year According to USAID (2013), the range of different crops cultivated by farmers could be a diversification strategy to minimize loss due to crop failure. However, this was also an indication of lack of specialization which may frustrate government programme of commercialization of agriculture. Commercialization encourages investment of resource in the most competitive crops (GoU, 2010). An average annual income earned by rice farmers was 1.6 million Ugandan shillings which was half of the total annual household income (3.5 million).

\subsection{Production Characteristics}

\subsubsection{Production Inputs and Output}

Table 2. Output and inputs used in production per hectare

\begin{tabular}{|c|c|c|c|c|c|c|}
\hline & \multicolumn{2}{|c|}{ NAEZ } & \multicolumn{2}{|c|}{ Lowland } & \multicolumn{2}{|c|}{ Upland } \\
\hline & Mean & Std. Dev. & Mean & Std. Dev. & Mean & Std. Dev. \\
\hline Output (tons) & $1.87 *$ & 1.559 & 2.1 & 1.714 & 1.64 & 1.351 \\
\hline Area (ha) & 0.63 & 0.64 & 0.47 & 0.347 & 0.8 & 0.802 \\
\hline Seeds (kgs) & $105.43^{*}$ & 51.513 & 118.76 & 57.442 & 92.11 & 40.712 \\
\hline Labour (days) & $248.93 *$ & 215.949 & 307.31 & 238.465 & 191.64 & 173.355 \\
\hline Ox-plough (days) & $10.08^{*}$ & 11.743 & 12.63 & 14.398 & 7.45 & 7.267 \\
\hline Tractor (hours) & $2.81 *$ & 2.016 & 3.91 & 2.601 & 2.27 & 1.392 \\
\hline
\end{tabular}

Note. T-test for the mean difference between the lowland and upland significance levels are represented by:* $1 \%$, ** 5\%, and $10 \%$; Labour and ox-plough were computed as 8 work hours per day. Tractor services were computed in hours.

\section{(1) Output per Hectare}

Information on rice production inputs and outputs are presented in Table 2. The average yield of rice for the NAEZ was $1.9 \mathrm{t} \mathrm{ha}^{-1}$ but there was significant mean difference between the production systems. The average yield from the lowland and upland farmers were $2.1 \mathrm{t} \mathrm{ha}^{-1}$ and $1.6 \mathrm{t} \mathrm{ha}^{-1}$, respectively. This finding is in agreement with earlier findings by Kijima (2012) at $2 \mathrm{t} \mathrm{ha}^{-1}$ in Kumi, Lira, and Dokolo districts. However, yield average obtained in the NAEZ fell below the national average of $2.5 \mathrm{t} \mathrm{ha}^{-1}$ (UBOS, 2015). Elsewhere in Kenya, farmers in Ahero irrigation scheme obtain yields as high as $5 \mathrm{t} \mathrm{ha}^{-1}$ (Onyango and Shikuku, 2013).

\section{(2) Area Cultivated}

Table 2 provide summary of area under production. The average area under rice cultivation was 0.63 hectares which was slightly above average for the entire country (UBOS, 2010). However, the field size varied from 0.47 hectares to 0.80 hectares for the lowland and upland systems, respectively. Test statistics for mean differences between the two systems was significant at less than $1 \%$. The difference between plot sizes could be explained by the fact that upland areas are open to expansion as opposed to wetland/lowland which is limited in size and access is restricted by National Environment Management Authority (NEMA). This is similar to Kijima (2012) explanation of the difference between plot sizes.

\section{(3) Seeds}

\section{(a) Seed Rate}

Farmers are planting $105 \mathrm{kgs} \mathrm{ha}^{-1}$ which was close to the recommended seed rate under broadcast planting (Table 2). However, the system averages revealed variation in amount of seeds planted with lowland using $119 \mathrm{kgs} \mathrm{ha}^{-1}$ while upland used only $92 \mathrm{kgs} \mathrm{ha}^{-1}$. According to Tsuboi (2011) and IRRI (2015), the recommended seed-rate is $50 \mathrm{kgs} \mathrm{ha}^{-1}$ and100 kgs ha ${ }^{-1}$ for the transplanted and broadcast, respectively. However, according to the results farmers used seed quantity outside recommended seed rate. Use of seed-rate contrary to the recommendation is not limited to this study. For example, Haneishi et al. (2013) reported $90 \mathrm{~kg}$ per hectare among rain-fed farmers in the country while Miyamoto et al. (2012) reported $110 \mathrm{kgs} \mathrm{ha}^{-1}$. Farmers using low rate face consequence of low plant populated which culminate into low yield. Those using higher rate are subject to wastage as well as low yield performance due to plant congestion (Tsuboi, 2011; IRRI, 2015). Accordingly, the reasons for high seeding rate among some farmers include; drought or floods which cause poor germination and farmer compensate by hiking 
seed quantity. Secondly, the quality of seed is very critical; farmer used local seed or grains and this compromise quality and germination.

\section{(b) Seed Type, Source and Variety}

Majority of the farmers in the NAEZ grew local seeds (67\%) with only $30 \%$ using improved seeds. Use of local seeds was more prevalence in lowland system ( $88 \%$ ) than the upland system $(45 \%)$. However, a total of $3 \%$ were not sure whether the seed type was local or improved. Seeds planted were accessed from different source; $71 \%$ of the seeds were from own saved source, grain markets constituted $18 \%$, seeds from fellow farmers was $5 \%$. Quality assured sources like seed company and development agencies such as research and extension were least accessed. The specific rice varieties being grown in the NAEZ was Nerica (28\%), Kaiso (27\%), Sindano (24\%), Supa (17\%) and the rest of other varieties (5\%). Lowland system cultivates mainly Kaiso (53\%) and Supa (31\%) due to their high water demand characteristics while the upland system grew Nerica (46\%) and Sindano (43\%) which have low water requirement (Figure 1).

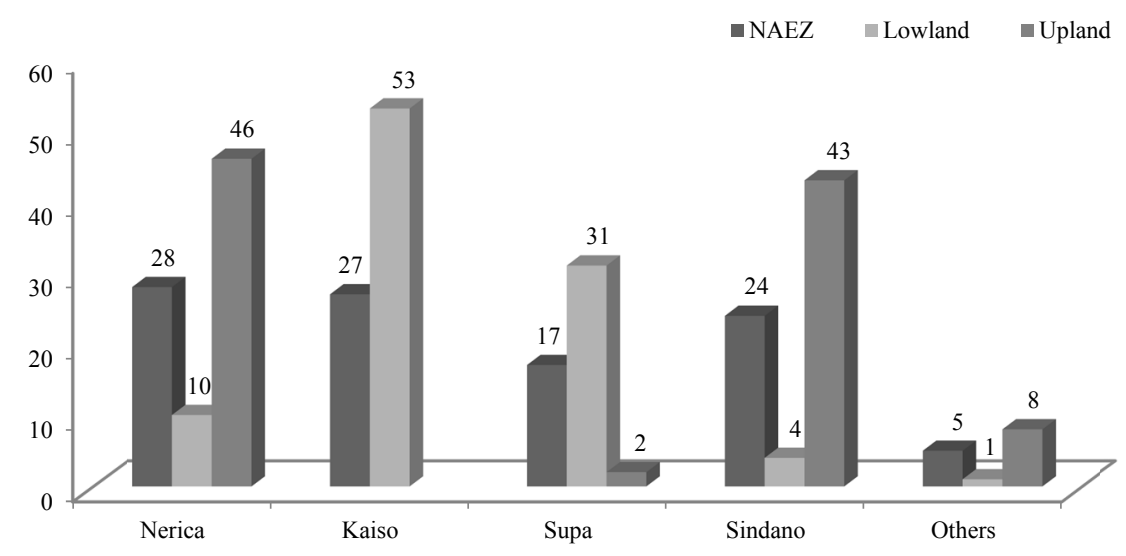

Figure 1. Rice variety

\section{(4) Labour}

(a) Man-Days per Hectare

The average labour used was 249 man-days per hectare in the NAEZ (Table 2). However, there was a significant difference in man-days of labour between the two systems. The number of man-days was greater in the lowland system (307 days) indicating intensiveness of production. High labour utilization in the lowland was mainly attributed to bird scaring (145.4 man-days). However, there was no difference in labour for weeding between the two systems. Haneishi et al. (2013) reported similar range in labour use between 200 to 430 man-days in the country. Miyamoto et al. (2012) reported labour usage as much as 229 man-days ha $^{-1}$ when bird scaring was excluded. Kijima et al. (2011) reported 250 and 410 man-days ha ${ }^{-1}$ in central and western region of the country, respectively. Conversely, Asimwe (2009) reported labour use at 1136 man-days ha $^{-1}$ in south-western region. High use of labour could be attributed to limited access to tractor (UBOS, 2010).

(b) Type of Labour and Gender 


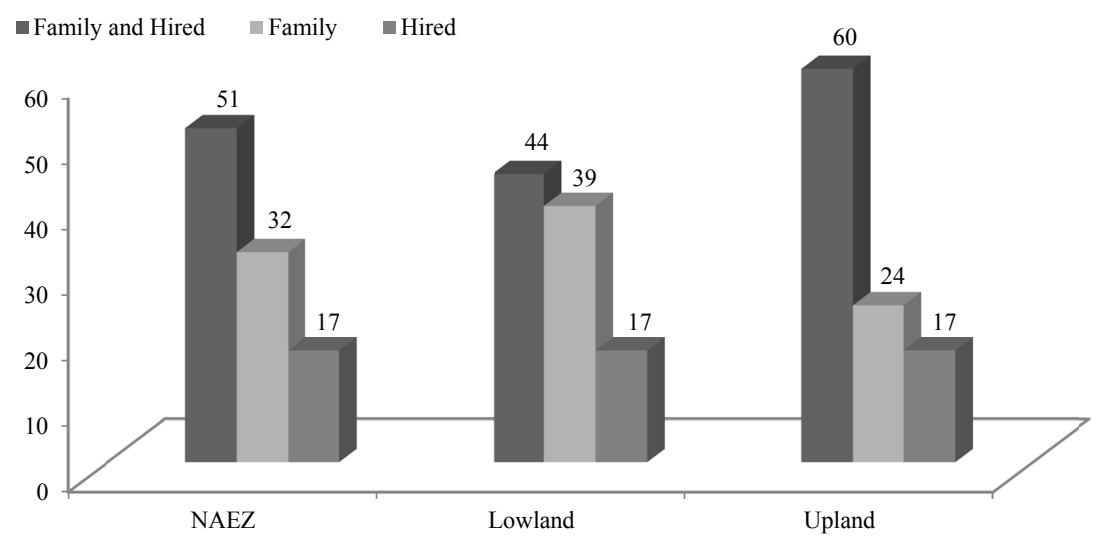

Figure 2. Types of labour

A total of $51 \%$ of labour in the NAEZ was obtained from both family and hired labour; family labour alone contributed $32 \%$ while purely hired labour was $17 \%$ (Figure 2 ). In respect to the two systems, family labour was more sourced among farmers in the lowland (39\%) than the upland system (24\%). Gender involvement in rice activities revealed that a total of $75 \%$ of labour were contributed by both men and women in the NAEZ. Gender participation in rice activities as per the two systems revealed that more women were involved $(15 \%)$ in the upland than the lowland (12\%).

(5) Ox-Plough

Ox-plough is an important implement for land preparation and planting of rice and it is highly appreciated as a handy substitute to tractor due to ease of accessibility. On average farmers spend 10 oxen-days per hectare in land preparation to planting of rice (Table 2). Use of ox-plough was found to be more intense in lowland system (13 oxen-days) while farmers in the upland were less inclined to using ox-plough to support land preparation and planting. The difference in use of ox-plough between the two systems was statistically significant at less than $1 \%$. Even at the activity level, more use of ox-plough was exhibited in the lowland than upland. Farmers in the lowland system rely heavily on ox-plough for operational activities and that was why it had the highest days. While in the case of upland cultivators, the soils are light and ploughing can easily be done using hand-hoe/manual labour (GoU, 2012).

(6) Tractor

Table 2 provides summary of hours used to plough one hectare of rice. The result showed that more tractor hours were spent in land preparation in the lowland fields than upland. Approximately 4 hours per hectare was used during ploughing of gardens located in the lowland. However, the upland fields required only 2 hours to complete ploughing one hectare.

(7) Agro-Chemicals

Table 3. Use of fertilizer and herbicides (percentage)

\begin{tabular}{llll}
\hline & NAEZ & Lowland & Upland \\
\hline Fertiliser & & & \\
Yes & 0.4 & 0.8 & 0 \\
No & 99.6 & 99.2 & 100 \\
\hdashline Herbicides & 9.6 & 17.8 & 1.0 \\
Yes & 90.4 & 82.3 & 98.5 \\
No & 5.0 & 6.3 & 1.4 \\
\hdashline Pesticides & 95.0 & 93.7 & 98.6 \\
Yes & & \\
No & & & \\
\hline
\end{tabular}


Rice production in the NAEZ is characterized by low use of fertilizer (Table 3). In fact, only $0.4 \%$ of the rice farmers were using fertilisers in the entire NAEZ. Use of fertilizer to boost crop production was evidently absent in the upland system. In the lowland system, a proportion of $0.8 \%$ of the farmers used fertilizer in their rice fields. Although herbicide is thought to be one of labour saving technologies in weed management, the importance of herbicides in weed control among the sampled farmers was insignificant as reported by only $9.6 \%$ of the farmers. Farmers in the lowland system accounted for the proportion of farmers using herbicides (17.8\%). Kijima (2012) also noted low use of herbicides where he reported only $4 \%$ of rice plots with application of herbicide on average in the region due to high costs and lack of knowledge. Prevalence of use of pesticides by the farmers in peat and disease management was only $5 \%$ in the NAEZ, lowland (6.3\%) and upland (1.4\%).

\subsubsection{Production Practices}

\section{(1) Seasonal Calendar}

Table 4. Season for rice production (percentage)

\begin{tabular}{llll}
\hline & NAEZ & Lowland & Upland \\
\hline First season & 84 & 79 & 90 \\
Second season & 16 & 21 & 10 \\
\hline
\end{tabular}

Two rice growing seasons were identified in the NAEZ. However, most of the rice was grown during the first than the second season (Table 4). Most of the upland (90\%) rice was planted during the first season compared to the lowland $(79 \%)$.

Table 5. Reasons for choice of season for rice production (percentage)

\begin{tabular}{llll}
\hline & NAEZ & Lowland & Upland \\
\hline Climate variability & 52 & 51 & 54 \\
Bird damage & 19 & 22 & 13 \\
Labor constraint & 18 & 16 & 20 \\
Land & 10 & 10 & 10 \\
Market & 1 & 0 & 3 \\
\hline
\end{tabular}

A number of reasons were advanced for selecting a particular planting season (Table 5). For example, timely planting due to variability in climate accounted for $52 \%$. Bird damage though considered a serious constraint in rice production, accounted for only $19 \%$ as a reason for choosing planting season. This is because the solution to bird damage lies with the communities than climate related issues. Constraint of labour accounted for $18 \%$ in the NAEZ, lowland (16\%) and upland (20\%) as a reason for selecting planting season. Lack of land (10\%) was also one of the reasons for preference a planting season.

(2) Months for Carrying Out Production Activities

Table 6 provides summary of monthly activities from seedbed preparation, planting, weeding, bird scaring and harvesting of rice. 
Table 6. Months for rice production activities (percentage)

\begin{tabular}{lccc}
\hline & NAEZ & Lowland & Upland \\
\hline $\begin{array}{l}\text { Months for ploughing } \\
\text { November to February }\end{array}$ & 50.3 & & \\
March to September & 49.7 & 59.1 & 41.4 \\
\hdashline $\begin{array}{l}\text { Months for planting } \\
\text { February to May }\end{array}$ & 70.3 & 40.8 & 58.5 \\
June to September & 29.9 & 31.3 & 71.8 \\
\hline $\begin{array}{l}\text { Months for weeding } \\
\text { March to June }\end{array}$ & 67.3 & 63.6 & 28.2 \\
July to October & 32.8 & 36.4 & 70.7 \\
\hline $\begin{array}{l}\text { Months for bird scaring } \\
\text { May to August }\end{array}$ & 52 & 56.4 & 29.2 \\
September to October & 48.1 & 43.6 & 47.7 \\
\hline Months for harvesting & & & 52.4 \\
June to September & 44.8 & 45.2 & \\
October to December & 55.2 & 54.8 & 54.4 \\
\hline
\end{tabular}

\section{(a) Seedbed Preparation}

Rice production activities take place throughout the year from seedbed preparation to harvesting. Slightly over $50 \%$ of the farmers in the NAEZ undertook seed bed preparation between November and February. However, $49 \%$ of the farmers prepared seedbed during planting time which fell between March and September. Timing of seedbed preparation varied between the two systems. A total of $59 \%$ of farmers in the lowland prepared seedbed as early as November to February. The upland system however, begins seedbed preparation during planting months which runs from March to September and this category also accounted for approximately $59 \%$. The period spent in seedbed preparation to planting was approximately 2 months in the NAEZ. However, the lag period between seedbed preparation and planting of seeds varied between the two systems and the difference was significant. The lowland farmers took duration of approximately 3 months from ploughing to fine tune seedbed for planting. However, the upland farmers took only 2 months implying that adequate attention was not given to the soil to get ready before planting. The mean ploughing frequency in the NAEZ was 2.2 implying that rice garden/fields needs at least two ploughing before planting seeds and this was done by $54 \%$ of the farmers. Mean difference in ploughing frequency was exhibited in the two systems where $52 \%$ of farmers in lowland prepare seedbed approximately thrice (2.5) before planting. However, $67 \%$ of farmers in the upland hardly ploughed rice garden twice (1.9) before planting seeds. The study observed marked difference in ploughing frequency between upland and lowland farms thus agreeing with Odogola (2006) that frequency of field leveling is dictated by the environment in which rice is grown. Good seedbed is critically important for even water storage, suitable soil texture for sowing, germination, easy penetration of seedling roots and weed management (IRRI, 2015).

(b) Planting

Planting was done in two phases, $70 \%$ of the farmers in the NAEZ planted at the start of first season which was February to May. Only 30\% planted rice between June and September. However, the difference in the planting month between lowland and upland systems was not pronounced. The two common methods of planting rice for both systems was broadcasting and transplanting although broadcasting $(84 \%)$ was more prevalent than transplanting (16\%). Interestingly, transplanting was more common in the lowland system where it accounted for $32 \%$ of the methods.

(c) Weeding

Sixty seven percent of the farmers reported that much of the weeding was done between March and June as opposed to July-October reported by $33 \%$ of the farmers. Weeding frequency of rice field was approximately 1.9 (about twice) and this was undertaken by $62 \%$ of the farmers in the NAEZ. However, there was a significant mean difference in weeding frequency between lowland (1.8) and upland (2.1) systems. On average weeding start two weeks after germination and weeding frequency is usually one to three times on average depending on the level of weed infestation. IRRI (2015) recommended that weeding should be done within the first 20-50 days after crop establishment but weeding after panicle initiation only helps to prevent weeds shedding seeds in future crops. 


\section{(d) Bird Scaring}

Bird scaring is done between May and August (52\%), the proportion of farmers who scared birds after September were $48 \%$. According to the farmers bird scaring is relaxed after October because damage is less severe around this time. Secondly, the optimum period for maturity of most cereal grain occur later in the year and this give farmer's room to spread damage risks to the rest of other cereals such as millet and sorghum.

(e) Harvesting

Harvesting of grains for first season crops begin from June to September (45\%), the optimum months for harvesting grains is September to October where most of the first and early second season crops are harvested. However, there was no significant difference in harvesting months between lowland and upland systems.

\subsection{Status of Climate in Rice Production}

The mean rainfall during crop production period was taken as monthly average between the planting and harvesting of rice crop (Table 7).

Table 7. Monthly mean rainfall in $\mathrm{mm}$

\begin{tabular}{lllllll}
\hline & NAEZ & Std. Dev. & Lowland & Std. Dev. & Upland & Std. Dev. \\
\hline $2013-2014$ & 153.8 & 64.64 & 143.2 & 39.63 & 164.3 & 81.07 \\
2013 & 146.3 & 51.57 & 150.4 & 24.39 & 142.2 & 68.66 \\
2014 & 127.0 & 33.37 & 149.6 & 24.68 & 104.3 & 24.31 \\
2015 & 141.9 & 34.27 & 156.2 & 37.89 & 127.5 & 22.53 \\
2016 & 199.9 & 93.62 & 116.6 & 51.99 & 283.2 & 29.99 \\
\hline
\end{tabular}

Rice production (planting to harvest) in the NAEZ occurs between March and November depending on variety and planting date (Akongo et al., 2017). The result of descriptive statistics revealed that the mean monthly rainfall during rice cropping season for the period 2013 to 2016 was $154 \mathrm{~mm}$ in the NAEZ. However, there were significant variations in the monthly average between seasons as well as systems. For instance, the upland system experienced relatively higher monthly average over the period 2013 to 2016 cropping period (164.3 $\mathrm{mm})$ than the lowland system $(143.2 \mathrm{~mm})$ during the same period. The results also indicated variability in mean monthly rain between seasons. Observations between seasons in different years showed zigzag trends with notable difference in the means. The rainfall amount during 2016 season was approximately $200 \mathrm{~mm}$ yet amount during 2014 was as low as $127 \mathrm{~mm}$.

\subsection{Disposal of Proceeds}

Table 8. Disposal of proceeds (percentage)

\begin{tabular}{llll}
\hline & NAEZ & Lowland & Upland \\
\hline School fees & 20.6 & 20.6 & 20.5 \\
Payment of bride price & 12.7 & 11.9 & 13.8 \\
Construction of house & 9.5 & 11.9 & 5.9 \\
Food items & 9.4 & 9.2 & 9.6 \\
Farm inputs & 11.3 & 10.7 & 12.2 \\
Purchase of land & 8.0 & 8.5 & 7.2 \\
Purchase of livestock & 15.3 & 15.3 & 15.4 \\
Others & 13.3 & 11.9 & 15.4 \\
\hline
\end{tabular}

Nearly all rice harvested was sold to earn income to meet the various household needs (Table 8). There was no significant difference in disposal of proceeds from rice among the two production systems. Slightly, over $20 \%$ of the farmers in the NAEZ sold rice to meet school fees requirement for their children. Livestock especially cattle 
was one of the household items bought using proceeds from rice (15\%). Livestock especially cattle (oxen) is available input for land preparation and planting of crops in the NAEZ. There was also a significant proportion of income from rice used for payment of bride price (12\%). Proceeds were also apportioned to purchase of farm inputs for subsequent crop production (11\%) and purchase of land (8\%). Over $9 \%$ of the proceeds were used on food items and construction of a house while the rest of other household needs constitute $13 \%$.

\subsection{Constraints in Production}

Table 9. Constraints in rice production (percentage)

\begin{tabular}{llll}
\hline & NAEZ & Lowland & Upland \\
\hline Variability in climate & 29.3 & 29.3 & 29.2 \\
Pest and Diseases & 15.7 & 20.9 & 10.6 \\
Labour constraints & 19.1 & 16.5 & 21.7 \\
Poor market prices & 10.5 & 7.3 & 13.7 \\
Weed infestation & 8.4 & 6.2 & 10.6 \\
Poor seed variety & 6.4 & 6.6 & 6.2 \\
Bird damage & 6.1 & 8.4 & 3.7 \\
Limited knowledge & 3.5 & 3.3 & 3.7 \\
Declining soil fertility & 1.0 & 1.5 & 0.6 \\
\hline
\end{tabular}

Inquiring was made on challenges faced by the farmers in rice production (Table 9) in the NAEZ. The situation was perceived as a constraint to production based on late onset of rain, inadequacy and short duration accompanied by drought situation. The perceived challenge of climate by the farmers in this study agrees with report by USAID (2013) that onset of rainy seasons can shift by 15 to 30 days (earlier or later), while the length of the rainy season can change by 20 to 40 days. Odogola (2006) also found 69\% of rice farmers were prone to drought and therefore vulnerable to total crop loss depending on the growth stage. Infestation by pest and diseases accounted for $16 \%$ of the constraints in the NAEZ. However, pest and disease infestation was higher in the lowland (21\%) and according to the farmers, high crop infestation occurs during flooding and drought periods.

Constraint of labour was $19 \%$ in production in the NAEZ. The constraint was more prevalent among farmers in the upland system $(22 \%)$ than their counterparts in the lowland $(16 \%)$. One of the reasons for the variation in the prevalence of labour challenge was high use of ox-plough among the lowland farmers. Weed infestation was reported as a constraint by $8 \%$ of the farmers in the NAEZ. Fields in the upland were highly affected (11\%) than the lowland system (6\%). The finding agrees with results in Figure 9 where weeding frequency was higher in the upland.

Although, market is readily available, farmers in the zone complained of low prices offered by the middlemen $(10 \%)$. The problem of low prices was more severe in the upland system (14\%) since they grow varieties that are not aromatic and therefore fetch low prices. Poor rice seed variety was experienced by $6 \%$ of farmers in the NAEZ. The constraint of poor seeds confirmed results in section 3.2 .1 (3), where over $67 \%$ and $18 \%$ of the farmers used local seed varieties and seeds obtained from grain markets, respectively. Bird damage constituted $6 \%$ of the constraints, lack of knowledge in rice production accounted for $3.5 \%$ while declining soil fertility was $1 \%$.

\section{Conclusion and Recommendations}

The objective of this paper was to analyse characteristics of rice production systems in the NAEZ. And the study has concluded as follows:

(1) There was a marked difference in yield, input application and production practice among upland and lowland systems

(2) Average yield per hectare was generally low

(3) Variability in climate, pest and diseases, low involvement of household members and lack of specialization may pose a challenge to rice production in the NAEZ.

Based on the findings, the study gives the following recommendations;

(4) Government should provide tailor made weather forecast information on specific crop and agro-ecological 
zones as well as introduction of small scale irrigation to promote cultivation in the upland areas.

(5) Promotion of labour saving technologies to ease labour use intensity, promote mechanization and specialization in rice production.

(6) Further research into system based effects of climate on rice productivity and farmers' adaptation.

\section{Acknowledgement}

This study was funded by the National Agricultural Research Organization (ATAAS project) .We are grateful to the farmers in Amuru, Gulu, Lira and Oyam who provided the data.

\section{Reference}

Akongo, G. O., Gombya-Ssembajjwe, W., Buyinza, M., \& Bua, A. (2016). Effects of climate variability on technical efficiency of rice in Lango and Acholi sub-regions, Uganda. Journal of Economics and Sustainable Development, 7(11).

Asiimwe, K. J. (2009). Technical efficiency of upland rice producers in south western Uganda (Unpublished master's thesis, Makerere University).

Bagamba, F. (2007). Market access and agricultural production, the case of banana production in Uganda (PhD thesis, University of Wageningen).

Bua, B., \& Ojirot, M. (2014). Assessing the Importance of Rice as Food and Income Security Crop in Puti-puti Sub-county, Pallisa District, Uganda. American Journal of Experimental Agriculture, 4(5), 532-540. https://doi.org/10.9734/AJEA/2014/6701

FAO/UNEP (Food and Agricultural Organisation/United Nations Environment Programme). (1992). Advisory services to Syria and Uganda on the formulation of national soils policies. FAO, Rome, Italy.

Global Water Initiative East Africa (GWIEA). (2013). Secure Water for Smallholder Agriculture Overview Brief Otuke District in Uganda (Brief: No. 2). Retrieved from http://www.gwieastafrica.org/media/GWIEA Uganda_Brief

Government of Uganda (GoU). (2009). The Uganda National Rice Development strategy (NRDS) lays out Uganda's strategy for promotion of rice production between 2009/10-2017/18. Retrieved from http://www.agriculture.go.ug

Government of Uganda (GoU). (2010). Agriculture Sector Development Strategy and Investment Plan: 2010/11-2014/15. Ministry of Agriculture, Animal Industry and Fisheries. Retrieved from http://www.agriculture.go.ug

Government of Uganda (GoU). (2012). The Project for Rural Road Network Development in Acholi Sub-Region in Northern Uganda (Volume 1: Summary Report).

Haneishi, Y., Maruyama, A., Asea, G., Okello, S. E., Tsuboi, T., Takagaki, M., \& Kikuchi, M. (2013). Exploration of rain-fed rice farming in Uganda based on a nationwide survey: Regionality, varieties and yield. African Journal of Agricultural Research, 8(29), 4038-4048. Retrieved from http://www.academicjournals.org/AJAR

Inter-governmental Panel on Climate Change (IPCC). (2007). Climate Change: Impacts, Adaptation and Vulnerability. Contribution of Working Group II to the Fourth Assessment Report of the IPCC (978-0521-88010-7 Hardback; 978-0521-70597-4 Paperback).

International Rice Research Institute (IRRI). (2015). Steps to successful rice production. Rice Knowledge Bank, International Rice Research Institute. Retrieved from http://www.knowledgebank.irri.org

International Union of Soil Sciences (IUSS). (2015). World Reference Base for Soil Resources 2014, update 2015. International soil classification system for naming soils and creating legends for soil maps (World Soil Resources Reports No. 106). FAO, Rome.

Kijima, Y. (2012). An empirical analysis of expanding rice production in sub-Sahara Africa expansion of lowland rice production and constraints on a rice green revolution: Evidence from Uganda (Working paper No. 49). JICA Research Institute.

Kijima, Y., Otsuka, K., \& Sserunkuuma, D. (2011). An inquiry into constraints on a green revolution in sub-Saharan Africa: The case of NERICA rice in Uganda. World Development, 39, 77-86. https://doi.org/10.1016/j.worlddev.2010.06.010 
Lira District Planning Unit (LDPU). (2011). Lira District Local Government Five Years Development Plan FY 2010/11 to 2014/2015. National Planning Authority, Kampala, Uganda. Retrieved from http://npa.ug/ wp-content/themes/npatheme/documents/North/Lira\%20DDP.pdf

Miyamoto, K., Maruyama, A., Haneishi, Y., Matsumoto, S., Tsuboi, T., Asea, G., ... Kikuchi, M. (2012). Nerica cultivation and its yield determinants: The case of upland rice farmers in Namulonge, Central Uganda. Journal of Agricultural Science, 4(6), 120-135. https://doi.org/10.5539/jas.v4n6p120

Odogola, R. W. (2006). Survey report on the status of rice production, processing and marketing in Uganda. Submitted to the Embassy of Japan in Uganda through JICA and Sasakawa Africa Association-Uganda.

Onyango, S. O., \& Shikuku, K. M. (2013). An analysis of technical efficiency of rice farmers in Ahero irrigation scheme, Kenya. Journal of Economics and Sustainable Development, 4(10), 9-16.

Oonyu, J. (2011). Upland rice growing: A potential solution to declining crop yields and the degradation of the Doho wetlands, Butaleja district-Uganda. African Journal of Agricultural Research, 6(12), 2774-2783.

STATA. (1996). A publication to promote communication among Stata users. Stata Technical STB-31 Bulletin.

Tsuboi, T. (2011). Rice cultivation handbook. National Agricultural Research Organization.

Uganda National Bureau of Statistics (UBOS). (2007). Uganda national household survey, 2005/2006: Report on agricultural module. Retrieved from http://www.ubos.org

Uganda National Bureau of Statistics (UBOS). (2010). Uganda Census of Agriculture 2008/2009 Volume 4: Crop Area and Production Report. Uganda Bureau of Statistics.

Uganda National Bureau of Statistics (UBOS). (2015). Statistical abstract. Retrieved from http://www.ubos.org/ publications/statistical-abstract

Uganda National Bureau of Statistics (UBOS). (2016). The National Population and Housing Census 2014 (Main Report). Kampala, Uganda. Retrieved from http://unstats.un.org/unsd/demographic/sources/census/ wphe/Uganda/UGA-2016-05-23.pdf

Uganda National Meteorology Authority (UNMA). (2017). Monthly mean rainfall and temperature for the last ten years collected from weather stations in Lira, Gulu and Kitgum.

United States Agency International Development (USAID). (2013). Uganda climate change Vulnerability assessment report. USAID African and Latin American Resilience to Climate Change (ARCC).

West African Rice Development Association (WARDA). (2001). New rice for Africa (NERICA) offers hope to Women farmers and millions more. Abidjan, Ivory Coast. Retrieved from http://www.warda.org/main/ Achivements/nerica.htm

\section{Copyrights}

Copyright for this article is retained by the author(s), with first publication rights granted to the journal.

This is an open-access article distributed under the terms and conditions of the Creative Commons Attribution license (http://creativecommons.org/licenses/by/4.0/). 